\title{
FORTY-NINTH ANNUAL LIST OF PAPERS
}

READ BEFORE THE AMERICAN MATHEMATICAL SOCIETY AND SUBSEQUENTLY

PUBLISHED, INCLUDING REFERENCE TO THE PLACES OF PUBLICATION

Adams, C. R., and Morse, A. P. Continuous additive functionals on the space $(B V)$ and certain subspaces. Read Dec. 2, 1939. Transactions of this Society, vol. 48, no. 1 (July, 1940), pp. 82-100.

Adkisson, V. W., and MacLane, Saunders. Extending maps of plane Peano continua. Read Oct. 28, 1939. Duke Mathematical Journal, vol. 6, no. 1 (March, 1940), pp. 216-228.

Agnew, R. P. On translations of functions and sets. Read Sept. 8, 1939. This Bulletin, vol. 46, no. 6 (June, 1940), pp. 525-530.

- On Tauberian theorems for double series. Read Feb. 24, 1940. American Journal of Mathematics, vol. 62, no. 3 (July, 1940), pp. 666-672.

- On kernels of faltung transformations. Read Sept. 7, 1939. Transactions of this Society, vol. 48, no. 1 (July, 1940), pp. 1-20.

- On continuity and periodicity of measurable functions. Read Oct. 28, 1939. Annals of Mathematics, (2), vol. 41, no. 4 (Oct., 1940), pp. 727-733.

- On rearrangements of series. Read Oct. 28, 1939. This Bulletin, vol. 46, no. 10 (Oct., 1940), pp. 797-799.

Alaoglu, Leon. Weak topologies of normed linear spaces. Read April 8, 1938. Annals of Mathematics, (2), vol. 41, no. 1 (Jan., 1940), pp. 252-267.

Albert, A. A. On ordered algebras. Read Dec. 2, 1939. This Bulletin, vol. 46, no. 6 (June, 1940), pp. 521-522.

- On p-adic fields and rational division algebras. Read Dec. 27, 1939. Annals of Mathematics, (2), vol. 41, no. 3 (July, 1940), pp. 674-693.

Alexander, H. W. The role of the mean curvature in the immersion theory of surfaces. Read Sept. 9, 1937 and Dec. 28, 1939. Transactions of this Society, vol. 47, no. 2 (March, 1940), pp. 230-253.

Allendoerfer, C. B. Rigidity for spaces of class greater than one. Read April 10, 1937. American Journal of Mathematics, vol. 61, no. 3 (July, 1939), pp. 633-644.

- The Euler number of a Riemann manifold. Read April 8 and Dec. 30, 1938, and Oct. 28, 1939. American Journal of Mathematics, vol. 62, no. 2 (April, 1940), pp. 243-248.

Ambrose, Warren. On measurable stochastic processes. Read Sept. 8, 1939. Transactions of this Society, vol. 47, no. 1 (Jan., 1940), pp. 66-79. See Doob, J. L.

Archibald, R. G. Relatively highly composite numbers. Read Sept. 6, 1938. Transactions of the Royal Society of Canada, (3), Section III, vol. 33 (May, 1939), pp. 11-27.

Arnold, H. E., and Parente, A. R. On the rational plane quartic curve with triple point. Read Feb. 22, 1930. National Mathematics Magazine, vol. 14, no. 3 (Dec., 1939), pp. 138-140.

Aucoin, A. A. Diophantine equations of degree n. Read Dec. 2, 1939. This Bulletin, vol. 46, no. 4 (April, 1940), pp. 334-339.

Ayres, W. L. A note on the definition of arc-sets. Read Dec. 1, 1939. This Bulletin, vol. 46, no. 10 (Oct., 1940), pp. 794-796.

Baer, Reinhold. Duality and commutativity of groups. Read April 7, 1939. Duke Mathematical Journal, vol. 5, no. 4 (Dec., 1939), pp. 824-838.

- Nilpotent groups and their generalizations. Read Sept. 5, 1939. Transactions of this Society, vol. 47, no. 3 (May, 1940), pp. 393-434. 
Nets and groups. II. Read April 13, 1940. Transactions of this Society, vol. 47, no. 3 (May, 1940), pp. 435-439.

A Galois theory of linear systems over commutative fields. Read Sept. 8, 1939. American Journal of Mathematics, vol. 62, no. 3 (July, 1940), pp. 551-588.

- Sylow theorems for infinite groups. Read April 13, 1940. Duke Mathematical Journal, vol. 6, no. 3 (Sept., 1940), pp. 598-614.

- Abelian groups that are direct summands of every containing abelian group. Read Feb. 24, 1940. This Bulletin, vol. 46, no. 10 (Oct., 1940), pp. 800-806.

Bardell, R. H. The inequalities of Morse when the maximum type is at most three. Read April 8, 1938. This Bulletin, vol. 46, no. 4 (April, 1940), pp. 242-245.

Barnett, I. A., and Reingold, Haim. Invariants of a system of linear homogeneous differential equations of the second order. Read Sept. 5, 1934. Duke Mathematical Journal, vol. 6, no. 1 (March, 1940), pp. 141-147.

Barnett, I. A., and Szász, Otto. On a certain Diophantine equation. Read April 15, 1939. American Mathematical Monthly, vol. 46, no. 9 (Nov., 1939), pp. 545-554.

Barone, H. G. Limit points of sequences and their transforms by methods of summability. Read April 8, 1939. Duke Mathematical Journal, vol. 5, no. 4 (Dec., 1939), pp. 740-752.

Becker, M. F., and MacLane, Saunders. The minimum number of generators for inseparable algebraic extensions. Read Oct. 28, 1939. This Bulletin, vol. 46, no. 2 (Feb., 1940), pp. 182-186.

Bell, Clifford. The solution of numeral equations. Read April 15, 1939. National Mathematics Magazine, vol. 14, no. 8 (May, 1940), pp. 435-438.

Bell, E. T. Postulational bases for the umbral calculus. Read April 6, 1940. American Journal of Mathematics, vol. 62, no. 4 (Oct., 1940), pp. 717-724.

Bell, P. O. The first canonical pencil. Read April 9, 1937. Duke Mathematical Journal, vol. 5, no. 4 (Dec., 1939), pp. 784-788.

- Projective analogues of the congruence of normals. Read Dec. 2, 1939. American Journal of Mathematics, vol. 62, no. 3 (July, 1940), pp. 680-686.

Bergman, Stefan. The approximation of functions satisfying a linear partial differential equation. Read Dec. 27, 1939. Duke Mathematical Journal, vol. 6, no. 3 (Sept., 1940), pp. 537-561.

- Boundary values of functions satisfying a linear partial differential equation of elliptic type. Read Sept. 12, 1940. Proceedings of the National Academy of Sciences, vol. 26, no. 11 (Nov., 1940), pp. 668-671.

Bergman, Stefan, and Martin, W. T. A modified moment problem in two variables. Read Sept. 8, 1939. Duke Mathematical Journal, vol. 6, no. 2 (June, 1940), pp. 389-407.

Bernstein, B. A. Groups and Abelian groups in terms of negative addition and negation. Read April 15, 1939. Duke Mathematical Journal, vol. 5, no. 4 (Dec., 1939), pp. 871-874.

Birkhoff, Garrett. An ergodic theorem for general semi-groups. Read Dec. 29, 1939. Proceedings of the National Academy of Sciences, vol. 25, no. 12 (Dec., 1939), pp. 625-627.

- Neutral elements in general lattices. Read Sept. 8, 1939. This Bulletin, vol. 46, no. 8 (Aug., 1940), pp. 702-705.

—L Lattice Theory. Read Sept. 6, 1938 and Sept. 8, 1939. American Mathematical Society Colloquium Publications, vol. 25, 1940. $151 \mathrm{pp}$.

Birnbaum, Z. W., and Zuckerman, H. S. On the properties of a collective. Read Feb. 24, 1940. American Journal of.Mathematics, vol. 62, no. 4 (Oct., 1940), pp. 787-791. 
Blumenthal, L. M., and Thurman, G. R. The characterization of pseudo-spherical sets. Read Dec. 28, 1938. American Journal of Mathematics, vol. 62, no. 4 (Oct., 1940), pp. 835-854.

Boas, R. P. Entire functions bounded on a line. Read Sept. 8, 1939. Duke Mathematical Journal, vol. 6, no. 1 (March, 1940), pp. 148-169.

- - A completeness theorem. Read Dec. 29, 1939. American Journal of Mathematics, vol. 62, no. 2 (April, 1940), pp. 312-318.

- Some uniqueness theorems for entire functions. Read Dec. 27, 1939. American Journal of Mathematics, vol. 62, no. 2 (April, 1940), pp. 319-324.

- Univalent derivatives of entire functions. Read April 26, 1940. Duke Mathematical Journal, vol. 6, no. 3 (Sept., 1940), pp. 719-721.

- Expansions of analytic functions. Read April 27, 1940. Transactions of this Society, vol. 48 , no. 3 (Nov., 1940), pp. 467-488.

Bochner, Salomon. Harmonic surfaces in Riemann metric. Read Oct. 28, 1939. Transactions of this Society, vol. 47, no. 1 (Jan., 1940), pp. 146-154.

- Finitely additive integral. Read Dec. 29, 1939. Annals of Mathematics, (2), vol. 41, no. 3 (July, 1940), pp. 495-504.

Bohnenblust, H. F. An axiomatic characterization of $L_{p}$-spaces. Read Dec. 2, 1939. Duke Mathematical Journal, vol. 6, no. 3 (Sept., 1940), pp. 627-640.

Bourgin, D. G. The clamped square sheet. Read Dec. 28, 1931 and Jan. 2, 1936. American Journal of Mathematics, vol. 61, no. 2 (April, 1939), pp. 417-439.

- Closure of products of functions. Read Dec. 2, 1939. This Bulletin, vol. 46, no. 10 (Oct., 1940), pp. 807-815; no. 12 (Dec., 1940), p. 970.

Bourgin, D. G., and Duffin, R. J. The Dirichlet problem for the vibrating string equation. Read Dec. 2, 1939. This Bulletin, vol. 45, no. 12 (Dec., 1939), pp. 851-858.

Brauer, A. T. On the non-existence of the Euclidean algorithm in certain quadratic number fields. Read Oct. 28, 1939. American Journal of Mathematics, vol. 62, no. 4 (Oct., 1940), pp. 697-716.

Brauer, Richard, and Nesbitt, Cecil. On the modular representations of groups of finite order, I. Read Oct. 30, 1937. University of Toronto Studies, Mathematical Series, no. 4. Toronto, 1937. 24 pp.

Brown, G. W. Reduction of a certain class of composite statistical hypotheses. Read Sept. 10, 1940. Annals of Mathematical Statistics, vol. 11, no. 3 (Sept , 1940), pp. $254-270$.

Burington, R. S. On circavariant matrices and circa-equivalent networks. Read Nov. 25, 1938. Transactions of this Society, vol. 48, no. 3 (Nov., 1940), pp. 377-390.

Bush, L. E. An asymptotic formula for the average sum of the digits of integers. Read Feb. 24, 1940. American Mathematical Monthly, vol. 47, no. 3 (March, 1940), pp. $154-156$.

Cairns, S. S. Triangulated manifolds which are not Brouwer manifolds. Read April 26, 1940. Proceedings of the National Academy of Sciences, vol. 26, no. 5 (May, 1940), pp. 359-361; Annals of Mathematics, (2), vol. 41, no. 4 (Oct., 1940), pp. 792-795.

- Homeomorphisms between topological manifolds and analytic manifolds. Read Dec. 27, 1933, March 27, 1937, and Feb. 25 and Oct. 28, 1939. Annals of Mathematics, (2), vol. 41 , no. 4 (Oct., 1940), pp. 796-808.

Calkin, J. W. Functions of several variables and absolute continuity, I. Read April 13, 1940. Duke Mathematical Journal, vol. 6, no. 1 (March, 1940), pp. 170-186.

Campaigne, H. H. Partition hypergroups. Read April 8 and Dec. 29, 1938, and April 
14, 1939. American Journal of Mathematics, vol. 62, no. 3 (July, 1940), pp. 599612.

Carlitz, Leonard. Some sums involving polynomials in a Galois field. Read Dec. 29, 1939. Duke Mathematical Journal, vol. 5, no. 4 (Dec., 1939), pp. 941-947.

- $A$ set of polynomials. Read Dec. 29, 1939. Duke Mathematical Journal, vol. 6, no. 2 (June, 1940), pp. 486-504.

—Linear forms and polynomials in a Galois field. Read April 27, 1940. Duke Mathematical Journal, vol. 6, no. 3 (Sept., 1940), pp. 735-749.

Church, Alonzo. On the concept of a random sequence. Read April 8, 1939. This Bulletin, vol. 46, no. 2 (Feb., 1940), pp. 130-135.

Church, Randolph. Numerical analysis of certain free distributive structures. Read April 27, 1940. Duke Mathematical Journal, vol. 6, no. 3 (Sept., 1940), pp. 732-734.

Coburn, Nathaniel. A characterization of Schouten's and Hayden's deformation methods. Read Feb. 24, 1940. Journal of the London Mathematical Society, vol. 15, no. 2 (April, 1940), pp. 123-136.

Cohen, L. W. On the mean ergodic theorem. Read April 8, 1939. Annals of Mathematics, (2), vol. 41, no. 3 (July, 1940), pp. 505-509.

- On topological completeness. Read Dec. 27, 1939. This Bulletin, vol. 46, no. 8 (Aug., 1940), pp. 706-710.

Cole, Nancy. The index theorem for a calculus of variations problem in which the integrand is discontinuous. Read April 27, 1940. American Journal of Mathematics, vol. 62 , no. 2 (April, 1940), pp. 249-276.

Coolidge, J. L. Analytic systems of central conics in space. Read April 27, 1940. Transactions of this Society, vol. 48, no. 3 (Nov., 1940), pp. 359-376.

Courant, Richard. Conformal mapping of multiply connected domains. Read Dec. 30, 1938. Duke Mathematical Journal, vol. 5, no. 4 (Dec., 1939), pp. 814-823.

—- Soap film experiments with minimal surfaces. Read March 26, 1937. American Mathematical Monthly, vol. 47, no. 3 (March, 1940), pp. 167-174.

Courant, Richard, and Davids, Norman. Minimal surfaces spanning closed manifolds. Read Feb. 24, 1940. Proceedings of the National Academy of Sciences, vol. 26, no. 3 (March, 1940), pp. 194-199.

Coxeter, H. S. M. A method for proving certain abstract groups to be infinite. Read Sept. 6, 1938. This Bulletin, vol. 46, no. 4 (April, 1940), pp. 246-251.

- The polytope $2_{21}$, whose twenty-seven vertices correspond to the lines on the general cubic surface. Read April 16, 1938 and Sept. 7, 1939. American Journal of Mathematics, vol. 62 , no. 3 (July, 1940), pp. 457-486.

Dantzig, G. B. On the non-existence of tests of "Student's" hypothesis having power functions independent of $\sigma$. Read April 6, 1940. Annals of Mathematical Statistics, vol. 11, no. 2 (June, 1940), pp. 186-192.

Daus, P. H. Bisecting circles. Read April 6, 1940. American Mathematical Monthly, vol. 47, no. 8 (Oct., 1940), pp. 519-529.

Davids, Norman. See Courant, Richard.

Davis, Roderick. See Michal, A. D.

Day, M. M. The spaces $L^{p}$ with $0<p<1$. Read Feb. 24, 1940. This Bulletin, vol. 46, no. 10 (Oct., 1940), pp. 816-823.

DeCicco, J. J. An analog of the nine-point circle in the Kasner plane. Read Nov. 26, 1938. American Mathematical Monthly, vol. 46, no. 10 (Dec., 1939), pp. 627-634.

- The geometry of fields of lineal elements. Read March 26, 1937 and Sept. 6, 1938. Transactions of this Society, vol. 47, no. 2 (March, 1940), pp. 207-229. See Kasner, Edward. 
Dilworth, R. P. On complemented lattices. Read Sept. 8, 1939. Tôhoku Mathematical Journal, vol. 47, no. 1 (March, 1940), pp. 18-23.

_- Lattices with unique irreducible decompositions. Read Oct. 28, 1939. Annals of Mathematics, (2), vol. 41, no. 4 (Oct., 1940), pp. 771-777.

Dines, L. L. See Moskovitz, David.

Dodd, E. L. The substitutive mean and certain subclasses of this general mean. Read April 27, 1940. Annals of Mathematical Statistics, vol. 11, no. 2 (June, 1940), pp. 163-176.

Doob, J. L. Regularity properties of certain families of chance variables. Read Dec. 28, 1939. Transactions of this Society, vol. 47, no. 3 (May, 1940), pp. 455-486.

- The law of large numbers for continuous stochastic processes. Read April 14, 1939. Duke Mathematical Journal, vol. 6, no. 2 (June, 1940), pp. 290-306.

Doob, J. L., and Ambrose, Warren. On two formulations of the theory of stochastic processes depending upon a continuous parameter. Read Oct. 28, 1939. Annals of Mathematics, (2), vol. 41, no. 4 (Oct., 1940), pp. 737-745.

Douglas, Jesse. Geometry of polygons in the complex plane. Read Oct. 29, 1938. Journal of Mathematics and Physics, Massachusetts Institute of Technology, vol. 19, no. 2 (April, 1940), pp. 93-130.

- On linear polygon transformations. Read Oct. 29, 1938. This Bulletin, vol. 46, no. 6 (June, 1940), pp. 551-560.

- A new special form of the linear element of a surface. Read April 27, 1940. Transactions of this Society, vol. 48, no. 1 (July, 1940), pp. 101-116.

Dribin, D. M. Class field theory of solvable algebraic number fields. Read April 14, 1939. Proceedings of the National Academy of Sciences, vol. 25, no. 6 (June, 1939), pp. 289-290.

Duffin, R. J. See Bourgin, D. G.

Duffin, R. J., and Schaeffer, A. C. On the extension of a functional inequality of S. Bernstein to non-analytic functions. Read Sept. 6, 1938. This Bulletin, vol. 46, no. 4 (April, 1940), pp. 356-363.

Dunford, Nelson, and Pettis, B. J. Linear operations on summable functions. Read Dec. 30, 1938. Transactions of this Society, vol. 47, no. 3 (May, 1940), pp. 323-392.

Dushnik, Ben, and Miller, E. W. Concerning similarity transformations of linearly ordered sets. Read Sept. 8, 1939. This Bulletin, vol. 46, no. 4 (April, 1940), pp. 322-326.

Eaton, J. E. Associative multiplicative systems. Read Feb. 25, 1939. American Journal of Mathematics, vol. 62, no. 1 (Jan., 1940), pp. 222-232.

- Theory of cogroups. Read Oct. 28, 1939. Duke Mathematical Journal, vol. 6, no. 1 (March, 1940), pp. 101-107.

Eaton, J. E., and Ore, Oystein. Remarks on multigroups. Read Sept. 8, 1939. American Journal of Mathematics, vol. 62, no. 1 (Jan., 1940), pp. 67-71.

Eilenberg, Samuel. On a theorem of $P$. A. Smith concerning fixed points for periodic transformations. Read Dec. 29, 1939. Duke Mathematical Journal, vol. 6, no. 2 (June, 1940), pp. 428-437.

- On homotopy groups. Read Sept. 11, 1940. Proceedings of the National Academy of Sciences, vol. 26, no. 9 (Sept., 1940), pp. 563-565.

Evans, G. C. Surfaces of minimal capacity. Read Sept. 12, 1940. Proceedings of the National Academy of Sciences, vol. 26, no. 8 (Aug., 1940), pp. 489-491.

Feld, J. M. A continuous group of contact transformations containing the generalized pedal transformation. Read April 16, 1938. Tôhoku Mathematical Journal, vol. 46, no. 2 (Feb., 1940), pp. 252-260. 
- Polygons as fundamental elements in the geometry of plane cubic curves. Read April 8, 1939. National Mathematics Magazine, vol. 14, no. 7 (April, 1940), pp. 367-371.

Feller, W. K. On the integro-differential equations of purely discontinuous Markoff processes. Read Feb. 24, 1940. Transactions of this Society, vol. 48, no. 3 (Nov., 1940), pp. $488-515$.

Fialkow, Aaron. The conformal theory of curves. Read Oct. 28, 1939. Proceedings of the National Academy of Sciences, vol. 26, no. 6 (June, 1940), pp. 437-439.

Ficken, F. A. Cones and vector spaces. Read Sept. 8, 1939. American Mathematical Monthly, vol. 47, no. 8 (Oct., 1940), pp. 530-533.

Flexner, W. W. Character group of a relative homology group. Read Dec. 30, 1938. Annals of Mathematics, (2), vol. 41, no. 1 (Jan., 1940), pp. 207-214.

Folley, K. W. A property of a simply ordered set. Read Nov. 22, 1940. This Bulletin, vol. 46, no. 12 (Dec., 1940), pp. 940-942.

Friedman, Bernard. A note on convex functions. Read April 8, 1938. This Bulletin, vol. 46, no. 6 (June, 1940), pp. 473-474.

Friedrichs, K. O., and Stoker, J. J. The non-linear boundary value problem of the buckled plate. Read Dec. 29, 1938. Proceedings of the National Academy of Sciences, vol. 25, no. 10 (Oct., 1939), pp. 535-540.

Galbraith, A. S., and Warschawski, S. E. The convergence of expansions resulting from a self-adjoint boundary problem. Read April 7, 1939. Duke Mathematical Journal, vol. 6, no. 2 (June, 1940), pp. 318-340.

Garabedian, H. L. Theorems associated with the Riesz and the Dirichlet's series methods of summation. Read Dec. 26, 1939. This Bulletin, vol. 45, no. 12 (Dec., 1939), pp. 891-895.

- A new formula for the Bernoulli numbers. Read Dec. 29, 1939. This Bulletin, vol. 46 , no. 6 (June, 1940), pp. 531-533.

Garabedian, H. L., and Wall, H. S. Hausdorff methods of summation and continued fractions. Read April 13, 1940. Transactions of this Society, vol. 48, no. 2 (Sept., 1940), pp. 185-207.

Garrison, G. N. Quasi-groups. Read Dec. 29, 1939. Annals of Mathematics, (2), vol. 41 , no. 3 (July, 1940), pp. 474-487.

Givens, Wallace. Factorization and signatures of Lorentz matrices. Read Nov. 25, 1938. This Bulletin, vol. 46, no. 2 (Feb., 1940), pp. 81-85.

Gleyzal, André. Order types and structure of orders. Read Dec. 27, 1939. Transactions of this Society, vol. 48, no. 3 (Nov., 1940), pp. 451-466.

Goldstine, H. H. Minimum problems in the functional calculus. Read April 15, 1939. This Bulletin, vol. 46, no. 2 (Feb., 1940), pp. 142-149.

Gorn, Saul. On incidence geometries. Read Sept. 6, 1938. This Bulletin, vol. 46, no. 2 (Feb., 1940), pp. 158-167.

Graustein, W. C. Harmonic minimal surfaces. Read Dec. 29, 1939. Transactions of this Society, vol. 47, no. 2 (March, 1940), pp. 173-206.

Green, Louis. Twisted cubics associated with a space curve. Read Sept. 6, 1938. American Journal of Mathematics, vol. 62, no. 2 (April, 1940), pp. 285-306.

Griffin, Harriet. The abelian quasi-group. Read Dec. 29, 1939. American Journal of Mathematics, vol. 62, no. 4 (Oct., 1940), pp. 725-737.

Hall, D. W. On a decomposition of true cyclic elements. Read April 9, Oct. 29 and Dec. 30, 1938. Transactions of this Society, vol. 47, no. 2 (March, 1940), pp. 305-321.

Hall, D. W., and Whyburn, G. T. Arc- and tree-preserving transformations. Read Sept. 7 and Dec. 28, 1939. Transactions of this Society, vol. 48, no. 1 (July, 1940), pp. 63-71. 
Hall, Marshall. The position of the radical in an algebra. Read April 7, 1939. Transactions of this Society, vol. 48, no. 3 (Nov., 1940), pp. 391-404.

Hall, N. A. The number of representations function for binary quadratic forms. Read Sept. 6, 1938. American Journal of Mathematics, vol. 62, no. 3 (July, 1940), pp. 589-598.

- A formal expansion theory for functions of one or more variables. Read Nov. 27, 1937. This Bulletin, vol. 46, no. 10 (Oct., 1940), pp. 824-832.

Halperin, Israel. See von Neumann, John.

Hancock, Harris. Development of the Minkowski Geometry of Numbers. Read Nov. 30, 1935. New York, Macmillan, 1939. 839 pp.

Harrold, O. G. The non-existence of a certain type of continuous transformation. Read Nov. 26 and Dec. 30, 1938. Duke Mathematical Journal, vol. 5, no. 4 (Dec., 1939), pp. 789-793.

- A note on strongly irreducible maps of an interval. Read Sept. 12, 1940. Duke Mathematical Journal, vol. 6, no. 3 (Sept., 1940), pp. 750-752.

- Exactly $(k, 1)$ transformations on connected linear graphs. Read Dec. 26, 1939. American Journal of Mathematics, vol. 62, no. 4 (Oct., 1940), pp. 823-834.

- Continua of finite degree and certain product sets. Read Dec. 29, 1939. This Bulletin, vol. 46, no. 12 (Dec., 1940), pp. 951-952.

Hartman, Philip. An asymptotic formula for exponential integrals. Read Feb. 25, 1939. American Journal of Mathematics, vol. 62, no. 1 (Jan., 1940), pp. 115-121.

Hartman, Philip, and Kershner, R. B. On upper limit relations for number theoretical functions. Read Sept. 7, 1939. American Journal of Mathematics, vol. 62, no. 4 (Oct., 1940); pp. 780-786.

Hedlund, G. A. A new proof for a metrically transitive system. Read Feb. 24, 1940. American Journal of Mathematics, vol. 62, no. 2 (April, 1940), pp. 233-242. See Morse, Marston.

Heins, M. H. Extremal problems for functions analytic and single-valued in a doublyconnected region. Read April 15, 1939. American Journal of Mathematics, vol. 62, no. 1 (Jan., 1940), pp. 91-106.

Helmer, Olaf. Theorems of the Picard type. Read April 15, 1939. Duke Mathematical Journal, vol. 6, no. 1 (March, 1940), pp. 38-47.

- Divisibility properties of integral functions. Read Sept. 7, 1939. Duke Mathematical Journal, vol. 6, no. 2 (June, 1940), pp. 345-356.

Herzog, Fritz. Uniqueness theorems for rational functions. Read Feb. 24, 1940. This Bulletin, vol. 46, no. 12 (Dec., 1940), pp. 942-950.

Hestenes, M. R., and McShane, E. J. A theorem on quadratic forms and its application in the calculus of variations. Read April 8 and Dec. 29, 1939. Transactions of this Society, vol. 47, no. 3 (May, 1940), pp. 501-512.

Hille, Einar. Contributions to the theory of Hermitian series. Read April 7, 1939. Duke Mathematical Journal, vol. 5, no. 4 (Dec., 1939), pp. 875-936.

- Contributions to the theory of Hermitian series. II. The representation problem. Read Oct. 28, 1939. Transactions of this Society, vol. 47, no. 1 (Jan., 1940), pp. 80-94.

Hoel, P. G. A significance test for minimum rank in factor analysis. Read April 8, 1939. Psychometrika, vol. 4, no. 4 (Dec., 1939), pp. 245-253.

- The errors involved in evaluating correlation determinants. Read Dec. 2, 1939. Annals of Mathematical Statistics, vol. 11, no. 1 (March, 1940), pp. 58-65.

Hollcroft, T. R. Anomalous plane curve systems associated with singular surfaces. Read April 16, 1938. This Bulletin, vol. 46, no. 4 (April, 1940), pp. 252-257. 
Hummel, P. M. Continued fractions and matrices. Read Dec. 27, 1933. Tôhoku Mathematical Journal, vol. 46, no. 2 (Feb., 1940), pp. 340-359.

Huntington, E. V. Stirling's formula with remainder. Read April 8, 1939. Biometrika, vol. 31, nos. 3-4 (March, 1940), p. 390.

Hurwitz, Henry. Total regularity of general transformations. Read Feb. 24, 1940. This Bulletin, vol. 46, no. 10 (Oct., 1940), pp. 833-837.

Ingram, W. H. On the integral equations of continuous dynamical systems. Read Oct. 30, 1937. Philosophical Magazine, (7), vol. 30, no. 198 (July, 1940), pp. 16-38.

Jackson, Dunham. Orthogonal polynomials with auxiliary conditions. Read Sept. 7, 1939. Transactions of this Society, vol. 48, no. 1 (July, 1940), pp. 72-81.

Jackson, S. B. The four-vertex theorem for spherical curves. Read April 8, 1938. American Journal of Mathematics, vol. 62, no. 4 (Oct., 1940), pp. 795-812.

Jacobson, Nathan. Cayley numbers and normal simple Lie algebras of type $G$. Read Dec. 29, 1938. Duke Mathematical Journal, vol. 5, no. 4 (Dec., 1939), pp. 775-783.

- The fundamental theorem of the Galois theory for quasi-fields. Read April 7, 1939. Annals of Mathematics, (2), vol. 41, no. 1 (Jan., 1940), pp. 1-7.

- A note on hermitian forms. Read Oct. 28, 1939. This Bulletin, vol. 46, no. 4 (April, 1940), pp. 264-268.

James, R. D. Integers which are not represented by certain ternary quadratic forms. Read Nov. 26, 1938. Duke Mathematical Journal, vol. 5, no. 4 (Dec., 1939), pp. 948-962.

Jeffery, R. L. Functions of bounded variation and non-absolutely convergent integrals in two or more dimensions. Read April 11, 1936. Duke Mathematical Journal, vol. 5, no. 4 (Dec., 1939), pp. 753-774.

- Integration in abstract space. Read Sept. 12, 1940. Duke Mathematical Journal, vol. 6, no. 3 (Sept., 1940), pp. 706-718.

John, Fritz. Special solutions of certain difference equations. Read Sept. 7, 1939. Acta Mathematica, vol. 71, nos. 3-4 (1939), pp. 175-189.

Johnson, M. M. An extension of a covariant differentiation process. Read April 15, 1939. This Bulletin, vol. 46, no. 4 (April, 1940), pp. 269-271.

Jones, F. B. Almost cyclic elements and simple links of a continuous curve. Read Dec. 28, 1939. This Bulletin, vol. 46, no. 10 (Oct., 1940), pp. 775-783.

Kac, Mark. On a problem concerning probability and its connection with the theory of diffusion. Read. Dec. 29, 1939. This Bulletin, vol. 46, no. 6 (June, 1940), pp. 534537.

van Kampen, E. R. On uniformly almost periodic multiplicative and additive functions. Read Dec. 29, 1939. American Journal of Mathematics, vol. 62, no. 3 (July, 1940), pp. 627-634.

von Kármán, Theodore. The engineer grapples with nonlinear problems. Read Dec. 27, 1939. This Bulletin, vol. 46, no. 8 (Aug., 1940), pp. 615-683.

Kasner, Edward. Conformality in connection with functions of two complex variables. Read, Sept. 11, 1908. Transactions of this Society, vol. 48, no. 1 (July, 1940), pp. 50-62.

Kasner, Edward, and DeCicco, J. J. General trihornometry of second order. Read Sept. 8, 1939. Proceedings of the National Academy of Sciences, vol. 25, no. 9 (Sept., 1939), pp. 479-481.

- Transformation theory of integrable double-series of lineal elements. Read Feb. 24, 1940. This Bulletin, vol. 46, no. 2 (Feb., 1940), pp. 93-100.

- Equilong and conformal transformations of period two. Read Sept. 12, 1940. Proceedings of the National Academy of Sciences, vol. 26, no. 7 (July, 1940), pp. 471-476. 
- The conformal near-Moebius transformations. Read Feb. 24, 1940. This Bulletin, vol. 46, no. 10 (Oct., 1940), pp. 784-793.

Kelley, J. L. A decomposition of compact continua and related theorems on fixed sets under continuous transformations. Read Dec. 30, 1938. Proceedings of the National Academy of Sciences, vol. 26, no. 3 (March, 1940), pp. 192-194.

Kershner, R. B. Ergodic curves and the ergodic function. Read April 8, 1938 and April 15, 1939. American Journal of Mathematics, vol. 62, no. 2 (April, 1940), pp. 325345 .

- See Hartman, Philip.

King, Frederick. See Lowan, A. N.

Koehler, Fulton. Systems of orthogonal polynomials on certain algebraic curves. Read April 14, 1939. This Bulletin, vol. 46, no. 4 (April, 1940), pp. 345-351.

Koopman, B. O. The axioms and algebra of intuitive probability. Read Feb. 25, 1939. Annals of Mathematics, (2), vol. 41, no. 2 (April, 1940), pp. 269-292.

- The bases of probability. Read Feb. 24, 1940. This Bulletin, vol. 46, no. 10 (Oct., 1940), pp. 763-774.

Korzybski, Alfred. General Semantics: Extensionalization in Mathematics, Mathematical Physics and General Education: II. Thalamic Symbolism and Mathematics. III. Over Under Defined Terms. Read December 29, 1938 and December 26, 1939. Chicago, Institute of General Semantics, 1940.

Kraus, G. R., and Neelley, J. H. A note on the rational plane cubic curve. Read Sept. 9, 1937. National Mathematics Magazine, vol. 14, no. 3 (Dec., 1939), pp. 134-137.

Laderman, Jack. See Lowan, A. N.

Lancaster, O. E. Some results concerning the behavior at infinity of real continuous solutions of algebraic difference equations. Read Dec. 30, 1937. This Bulletin, vol. 46, no. 2 (Feb., 1940), pp. 169-177.

Lane, E. P. A theorem on surfaces. Read Dec. 2, 1939. This Bulletin, vol. 46, no. 2 (Feb., 1940), pp. 117-120.

Langer, R. E. On the stability of the laminar flow of a viscous fuid. Read Sept. 7, 1939. This Bulletin, vol. 46, no. 4 (April, 1940), pp. 257-263.

Langford, C. H. A theorem on deducibility for second-order functions. Read Dec. 29, 1937. Journal of Symbolic Logic, vol. 4, no. 2 (June, 1939), pp. 77-79.

Larguier, E. H. A matrix theory of n-dimensional measurement. Read Dec. 30, 1938. Duke Mathematical Journal, vol. 5, no. 4 (Dec., 1939), pp. 729-739.

Leighton, Walter. Proper continued fractions. Read Sept. 8, 1939. American Mathematical Monthly, vol. 47, no. 5 (May, 1940), pp. 274-280.

Levinson, Norman. On Hardy's theorem on the zeros of the zeta function. Read Dec. 26, 1939. Journal of Mathematics and Physics, Massachusetts Institute of Technology, vol. 19, no. 3 (July, 1940), pp. 159-160. Gap and Density Theorems. Read Dec. 29 and Dec. 30, 1938, and April 8, 1939. American Mathematical Society Colloquium Publications, vol. 26, 1940. 246 pp.

Lowan, A. N. On some problems in the diffraction of heat. Read April 8, 1939. Philosophical Magazine, (7), vol. 29, no. 192 (Jan., 1940), pp. 93-99.

Lowan, A. N., and King, Frederick. Note on the evaluation of the earth's temperature arising from radioactivity. Read Oct. 29, 1938. Physical Review, (2), vol. 54, no. 12 (Dec., 1938), pp. 1109-1110.

Lowan, A. N., and Laderman, Jack. On the distribution of errors in nth tabular differences. Read Oct. 28, 1939. Annals of Mathematical Statistics, vol. 10, no. 4 (Dec., 1939), pp. 360-364.

Lubben, R. G. Separabilities of arbitrary orders and related properties. Read Dec. 27, 1939. This Bulletin, vol. 46, no. 12 (Dec., 1940), pp. 913-919. 
McCoy, N. H. A generalization of Ostrowski's theorem on matrix identities. Read Sept. 8, 1939. This Bulletin, vol. 46, no. 6 (June, 1940), pp. 490-495.

McShane, E. J. Curve-space topologies associated with variational problems. Read Dec. 30, 1938. Annali della R. Scuola Normale Superiore di Pisa, (2), vol. 9, no. 1 (Jan., 1940), pp. 45-60.

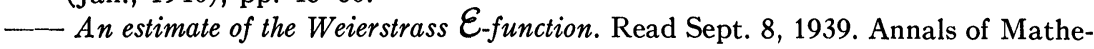
matics, (2), vol. 42 , no. 2 (April, 1940), pp. 314-320.

- A remark concerning sufficiency theorems for the problem of Bolza. Read Sept. 8, 1939. This Bulletin, vol. 46, no. 8 (Aug., 1940), pp. 698-701.

- Generalized curves. Read Sept. 6, 1939. Duke Mathematical Journal, vol. 6, no. 3 (Sept., 1940), pp. 513-536.

- See Hestenes, M. R.

MacLane, Saunders. Note on the relative structure of p-adic fields. Read Feb. 24, 1940. Annals of Mathematics, (2), vol. 41, no. 4 (Oct., 1940), pp. 751-753.

- See Adkisson, V. W.; Becker, M. F.

Maker, P. T. The ergodic theorem for a sequence of functions. Read April 8, 1939. Duke Mathematical Journal, vol. 6, no. 1 (March, 1940), pp. 27-30.

Mancill, J. D. On the Carathéodory condition for unilateral variations. Read Dec. 29, 1939. This Bulletin, vol. 46, no. 4 (April, 1940), pp. 363-366.

- The Jacobi condition for unilateral variations. Read Dec. 29, 1939. Duke Mathematical Journal, vol. 6, no. 2 (June, 1940), pp. 341-344.

Martin, M. H. Real asymptotic solutions of real differential equations. Read Dec. 29, 1938. This Bulletin, vol. 46, no. 6 (June, 1940), pp. 475-481.

Martin, R. S. See Michal, A. D.

Martin, W. T. Analytic functions and multiple Fourier integrals. Read Dec. 29, 1939. American Journal of Mathematics, vol. 62, no. 3 (July, 1940), pp. 673-679.

- On a minimum problem in the theory of analytic functions of several variables. Read Oct. 28, 1939. Transactions of this Society, vol. 48, no. 2 (Sept., 1940), pp. 351357.

- See Bergman, Stefan.

Menger, Karl. On Green's formula. Read April 13, 1940. Proceedings of the National Academy of Sciences, vol. 26, no. 11 (Nov., 1940), pp. 660-664.

Mewborn, A. B. See Michal, A. D.

Michal, A. D. Differentials of functions with arguments and values in topological abelian groups. Read April 27, 1940. Proceedings of the National Academy of Sciences, vol. 26, no. 5 (May, 1940), pp. 356-359.

Michal, A. D., Davis, Roderick, and Wyman, Max. Polygenic functions in general analysis. Read Sept. 8, 1939. Annali della R. Scuola Normale Superiore di Pisa, (2), vol. 9, no. 2 (April, 1940), pp. 97-107.

Michal, A. D., and Martin, R. S. Some expansions in vector space. Read Aug. 31, 1932. Journal de Mathématiques Pures et Appliquées, (9), vol. 13, no. 1 (1934), pp. 69-91.

Michal, A. D., and Mewborn, A. B. Géométrie différentielle projective générale des géodésiques généralisées. Read April 15, 1939. Comptes Rendus de l'Académie des Sciences, Paris, vol. 209, no. 8 (Aug., 1939), pp. 392-394.

- Abstract flat projective geometry. Read April 15, 1939. Proceedings of the National Academy of Sciences, vol. 25, no. 8 (Aug., 1939), pp. 440-443.

Milgram, A. N. Partially ordered sets and topology. Read April 12, 1940. Proceedings of the National Academy of Sciences, vol. 26, no. 4 (April, 1940), pp. 291-293. 
Miller, E. W. Some theorems on continua. Read April 10, 1937. This Bulletin, vol. 46, no. 2 (Feb., 1940), pp. 150-157.

- See Dushnik, Ben.

Miller, H. C. A theorem concerning closed and compact point sets which lie in connected domains. Read Feb. 24, 1940. This Bulletin, vol. 46, no. 10 (Oct., 1940), p. 848.

Montgomery, Deane, and Zippin, Leo. A theorem on the rotation group of the twosphere. Read Oct. 28, 1939. This Bulletin, vol. 46, no. 6 (June, 1940), pp. 520-521.

- Topological group foundations of rigid space geometry. Read Oct. 28 and Dec. 29, 1939. Transactions of this Society, vol. 48, no. 1 (July, 1940), pp. 21-49.

- Topological transformation groups. I. Read Sept. 8, 1939. Annals of Mathematics, (2), vol. 41 , no. 4 (Oct., 1940), pp. 778-791.

Moore, M. G. On expansions in series of exponential functions. Read Dec. 30, 1937. American Journal of Mathematics, vol. 62, no. 1 (Jan., 1940), pp. 83-90.

- Fundamental systems of solutions for linear difference equations. Read April 15, 1939. Duke Mathematical Journal, vol. 6, no. 3 (Sept., 1940), pp. 652-657.

Moore, R. L. Concerning the open subsets of a plane continuum. Read Dec. 29, 1936. Proceedings of the National Academy of Sciences, vol. 26, no. 1 (Jan., 1940), pp. 24-25.

Morrey, C. B. Existence and differentiability theorems for the solutions of variational problems for multiple integrals. Read Dec. 2, 1939. This Bulletin, vol. 46, no. 6 (June, 1940), pp. 439-458.

Morse, A. P., and Randolph, J. F. Gillespie measure. Read Sept. 10, 1937. Duke Mathematical Journal, vol. 6, no. 2 (June, 1940), pp. 408-419.

- See Adams, C. R.

Morse, Marston, and Hedlund, G. A. Symbolic dynamics II. Sturmian trajectories. Read Dec. 30, 1938. American Journal of Mathematics, vol. 62, no. 1 (Jan., 1940), pp. $1-42$.

Moskovitz, David, and Dines, L. L. On the supporting-plane property of a convex body. Read Sept. 5, 1939. This Bulletin, vol. 46, no. 6 (June, 1940), pp. 482-489.

Murray, F. J. Nullifying functions. Read Dec. 29, 1939. This Bulletin, vol. 46, no. 6 (June, 1940), pp. 459-465.

Neelley, J. H. See Kraus, G. R.

Nesbitt, Cecil. See Brauer, Richard.

von Neumann, John. The uniqueness of Haar's measure. Read April 10, 1936. Recueil Mathématique, vol. 43, no. 5 (1936), pp. 721-734.

von Neumann, John, and Halperin, Israel. On the transitivity of perspective mappings. Read Dec. 29, 1936. Annals of Mathematics, (2), vol. 41, no. 1 (Jan., 1940), pp. 87-93.

Niven, I. M. On a certain partition function. Read April 8, 1939. American Journal of Mathematics, vol. 62, no. 2 (April, 1940), pp. 353-364.

— Integers of quadratic fields as sums of squares. Read Dec. 29, 1939. Transactions of this Society, vol. 48, no. 3 (Nov., 1940), pp. 405-417.

Oldenburger, Rufus. Factorability of general symmetric matrices. Read Oct. 30, 1937. Compositio Mathematica, vol. 7, no. 2 (Nov., 1939), pp. 223-228.

- Higher dimensional determinants. Read Nov. 25, 1938. American Mathematical Monthly, vol. 47, no. 1 (Jan., 1940), pp. 25-33.

- Complete reducibility of forms. Read April 7, 1939. This Bulletin, vol. 46, no. 2 (Feb., 1940), pp. 88-92.

- Infinite powers of matrices and characteristic roots. Read Sept. 8, 1939. Duke Mathematical Journal, vol. 6, no. 2 (June, 1940), pp. 357-361. 
La teoria de los polinomios de orden superior. Read Sept. 12, 1940. Ingeniiria, Mexico City, vol. 14, no. 6 (June, 1940), pp. 192-201.

- Polynomials in several variables. Read April 13, 1940. Annals of Mathematics, (2), vol. 41, no. 3 (July, 1940), pp. 694-710.

- Binary forms. Read April 27, 1940. Proceedings of the National Academy of Sciences, vol. 26, no. 8 (Aug., 1940), pp. 497-499.

- Polynomials over fields. Read Dec. 30, 1937. National Mathematics Magazine, vol. 15, no. 1 (Oct., 1940), pp. 3-26.

- Convergence of Hardy Cross's balancing process. Read April 13, 1940. Journal of Applied Mechanics, American Society of Mechanical Engineers, vol. 7, no. 4 (Dec., 1940), pp. A-166-A-170.

Oldenburger, Rufus, and Porges, A. E. The minimal numbers of binary forms. Read April 13, 1940. This Bulletin, vol. 46, no. 8 (Aug., 1940), pp. 694-697.

Ore, Oystein. See Eaton, J. E.

Pall, Gordon. On the arithmetic of quaternions. Read April 15, 1933 and April 13, 1940. Transactions of this Society, vol. 47, no. 3 (May, 1940), pp. 487-500.

- On the rational automorphs of $x_{1}^{2}+x_{2}^{2}+x_{3}^{2}$. Read Sept. 1, 1936. Annals of Mathematics, (2), vol. 41, no. 4 (Oct., 1940), pp. 754-766.

Parente, A. R. See Arnold, H. E.

Patterson, W. A. Inverse problems of the calculus of variations for multiple integrals. Read Dec. 29, 1939. This Bulletin, vol. 46, no. 6 (June, 1940), pp. 502-511.

Paxson, E. W. Linear topological groups. Read Sept. 6, 1938. Annals of Mathematics, (2), vol. 40 , no. 3 (July, 1939), pp. 575-580.

Peebles, G. H. Some generalizations of the theory of orthogonal polynomials. Read Oct. 29, 1938. Duke Mathematical Journal, vol. 6, no. 1 (March, 1940), pp. 89-100.

Perlin, I. E. Indefinitely differentiable functions with prescribed least upper bounds. Read Sept. 8, 1939. This Bulletin, vol. 46, no. 4 (April, 1940), pp. 272-273.

Pettis, B. J. See Dunford, Nelson.

Phillips, R. S. Integration in a convex linear topological space. Read April 15, 1939. Transactions of this Society, vol. 47, no. 1 (Jan., 1940), pp. 114-145.

- $A$ decomposition of additive set functions. Read April 15, 1939. This Bulletin, vol. 46, no. 4 (April, 1940), pp. 274-277.

- On linear transformations. Read Dec. 29, 1939. Transactions of this Society, vol. 48, no. 3 (Nov., 1940), pp. 516-541.

Pitcher, Everett. Critical points of a map to a circle. Read Dec. 29, 1938 and Sept. 6, 1939. Proceedings of the National Academy of Sciences, vol. 25, no. 8 (Aug., 1939), pp. 428-431.

- Identification of two subsets. Read Sept. 8, 1939. Proceedings of the National Academy of Sciences, vol. 25, no. 8 (Aug., 1939), pp. 435-438.

Porges, A. E. See Oldenburger, Rufus.

Post, E. L. Polyadic groups. Read Oct. 26, 1935. Transactions of this Society, vol. 48, no. 2 (Sept., 1940), pp. 208-350.

Price, G. B. The theory of integration. Read Dec. 28, 1937. Transactions of this Society, vol. 47 , no. 1 (Jan., 1940), pp. 1-50.

- Definitions and properties of monotone functions. Read Sept. 6, 1938. This Bulletin, vol. 46, no. 2 (Feb., 1940), pp. 77-80.

- On the completeness of a certain metric space with an application to Blaschke's selection theorem. Read Dec. 28, 1938. This Bulletin, vol. 46, no. 4 (April, 1940), pp. 278-280. 
Puckett, W. T. On 0-regular surface transformations. Read April 8, 1939. Transactions of this Society, vol. 47, no. 1 (Jan., 1940), pp. 95-113.

- Regular transformations. Read Sept. 8, 1939. Duke Mathematical Journal, vol. 6, no. 1 (March, 1940), pp. 80-88.

Purcell, E. J. A multiple null-correspondence and a space Cremona involution of order 2n-1. Read Dec. 2, 1939. This Bulletin, vol. 46, no. 4 (April, 1940), pp. 339-344.

Rademacher, H. A. Fourier expansions of modular forms and problems of partition. Read Dec. 29, 1938. This Bulletin, vol. 46, no. 2 (Feb., 1940), pp. 59-73.

Rad6, Tibor, and Reichelderfer, P. V. Cyclic transitivity. Read Dec. 26, 1939. Duke Mathematical Journal, vol. 6, no. 2 (June, 1940), pp. 474-485.

Rad6, Tibor, and Youngs, J. W. T. On upper semi-continuous collections. Read April 8, 1939. Acta Litterarum ac Scientiarum, Szeged, vol. 9, no. 4 (1940), pp. 239-243.

Rainville, E. D. Linear differential invariance under an operator related to the Laplace transformation. Read Nov. 26, 1938. American Journal of Mathematics, vol. 62, no. 2 (April, 1940), pp. 391-405.

Randels, W. C. On the absolute summability of Fourier series. II. Read April 8, 1939. This Bulletin, vol. 46, no. 2 (Feb., 1940), pp. 86-88.

Randolph, J. F. Metric separability and outer integrals. Read Dec. 30, 1936 and Oct. 28, 1939. This Bulletin, vol. 46, no. 12 (Dec., 1940), pp. 934-939.

- See Morse, A. P.

Rawles, Thomas. The definition and consistency of index numbers. Read Jan. 2, 1936. Abstracts of Papers Presented at the Research Conference on Economics and Statistics held by the Cowles Commission for Research in Economics. Colorado College Publications, General Series, no. 208 (Sept., 1936), pp. 95-97.

Reichelderfer, P. V. See Radó, Tibor.

Reid, W. T. The Jacobi condition for the double integral problem of the calculus of variations. Read Oct. 31, 1936. Duke Mathematical Journal, vol. 5, no. 4 (Dec., 1939), pp. 856-870.

- $A$ theorem on continuous functions in abstract spaces. Read Sept. 8, 1939. This Bulletin, vol. 46, no. 2 (Feb., 1940), pp. 113-116.

Reingold, Haim. See Barnett, I. A.

Ritt, J. F. On the intersections of algebraic differential manifolds. Read Sept. 8, 1939. Proceedings of the National Academy of Sciences, vol. 25, no. 4 (April, 1939), pp. 214-215.

- On a type of algebraic differential manifold. Read Sept. 12, 1940. Transactions of this Society, vol. 48, no. 3 (Nov., 1940), pp. 542-552.

Roberts, J. H. Two-to-one transformations. Read Oct. 28, 1939. Duke Mathematical Journal, vol. 6, no. 1 (March, 1940), pp. 256-262.

Robertson, Fred. The general differential operator. Read Nov. 25, 1932 and Dec. 1, 1939. Iowa State College Journal of Science, vol. 14, no. 3 (April, 1940), pp. 261-266.

Robertson, M. S. Typically-real functions with $a_{n}=0$ for $n \equiv 0(\bmod 4)$. Read Sept. 8, 1939. This Bulletin, vol. 46, no. 2 (Feb., 1940), pp. 136-141.

Robinson, R. M. Stencils for Solving $x^{2} \equiv a(\bmod m)$. Read Sept. 12, 1940. Berkeley and Los Angeles, University of California Press, 1940. 14 pp. +272 Hollerith punched cards.

- On the mean values of an analytic function. Read Dec. 2, 1939. This Bulletin, vol. 46, no. 10 (Oct., 1940), pp. 849-851.

Rodabaugh, L. D. The partial differential equation $\partial z / \partial x+f(x, y) \partial z / \partial y=0$. Read April 8, 1939. Duke Mathematical Journal, vol. 6, no. 2 (June, 1940), pp. 362-374. 
Rosser, Barkley. A new lower bound for the exponent in the first case of Fermat's last theorem. Read Sept. 8, 1939. This Bulletin, vol. 46, no. 4 (April, 1940), pp. 299-304.

Rosser, Barkley, and Walker, R. J. The algebraic theory of diabolic magic squares. Read Feb. 26, 1938. Duke Mathematical Journal, vol. 5, no. 4 (Dec., 1939), pp. 705-728.

Schaeffer, A. C. See Duffin, R. J.

Schaeffer, A. C., and Szegö, Gabor. Polynomials whose real part is bounded on a given curve in the complex plane. Read Dec. 2, 1939. American Journal of Mathematics, vol. 62 , no. 4 (Oct., 1940), pp. 868-876.

Schilling, O. F. G. Regular normal extensions over complete fields. Read Oct. 28, 1939. Transactions of this Society, vol. 47, no. 3 (May, 1940), pp. 440-454.

Schoenberg, I. J. On metric arcs of vanishing Menger curvature. Read Dec. 27, 1939. Annals of Mathematics, (2), vol. 41, no. 4 (Oct., 1940), pp. 715-726.

Schwartz, H. M. A class of continued fractions. Read April 8, 1939. Duke Mathematical Journal, vol. 6, no. 1 (March, 1940), pp. 48-65.

Schweigert, G. E. A note on the limit of orbits. Read April 15, 1939. This Bulletin, vol. 46, no. 12 (Dec., 1940), pp. 963-969.

Scott, W. T. Approximation to real irrationals by certain classes of rational fractions. Read Feb. 24, 1940. This Bulletin, vol. 46, no. 2 (Feb., 1940), pp. 124-129.

Scott, W. T., and Wall, H. S. A convergence theorem for continued fractions. Read Sept. 8, 1939. Transactions of this Society, vol. 47, no. 1 (Jan., 1940), pp. 155172.

- Continued fraction expansions for arbitrary power series. Read Dec. 29, 1938 and April 15, 1939. Annals of Mathematics, (2), vol. 41, no. 2 (April, 1940), pp. 328349.

Sewell, W. E. Continuity and degree of approximation by rational functions. Read Oct. 28, 1939. Revista de Ciencias, vol. 41, no. 430 (Dec., 1939), pp. 435-451.

- See Walsh, J. L.

Shiffman, Max. The ring of automorphisms of an Abelian group. Read Sept. 6, 1938. Duke Mathematical Journal, vol. 6, no. 3 (Sept., 1940), pp. 579-597.

Shohat, J. A. Application of orthogonal Tchebycheff polynomials to Lagrangian interpolation and to the general theory of polynomials. Read April 7, 1939. Annali di Matematica, (4), vol. 18, nos. 3-4 (July-Dec., 1939), pp. 201-238.

Laguerre polynomials and the Laplace transform. Read Dec. 31, 1936. Duke Mathematical Journal, vol. 6, no. 3 (Sept., 1940), pp. 615-626.

Smiley, M. F. A note on measure functions in a lattice. Read Sept. 5, 1939. This Bulletin, vol. 46, no. 4 (April, 1940), pp. 239-241.

- The Jacobi condition for extremaloids. Read Dec. 29, 1939. Duke Mathematical Journal, vol. 6, no. 2 (June, 1940), pp. 425-427.

Smith, A. H. Summability of conjugate Fourier series. Read March 31, 1934. Duke Mathematical Journal, vol. 4, no. 2 (June, 1938), pp. 270-276.

Smith, C. D. Three-circle problems in modern geometry. Read Sept. 6, 1938. National Mathematics Magazine, vol. 14, no. 6 (March, 1940), pp. 299-307.

Spencer, D. C. On an inequality of Grunsky. Read Sept. 12, 1940. Proceedings of the National Academy of Sciences, vol. 26, no. 10 (Oct., 1940), pp. 616-621.

- On finitely mean valent functions. II. Read April 27, 1940. Transactions of this Society, vol. 48, no. 3 (Nov., 1940), pp. 418-435.

Springer, C. E. Metric geometry of surfaces in four-dimensional space. Read Sept. 9, 1937. Dissertation, University of Chicago, 1938. 53 pp. 
Steenrod, N. E. Regular cycles of compact metric spaces. Read Sept. 7, 1939. Annals of Mathematics, (2), vol. 41, no. 4 (Oct., 1940), pp. 833-851.

Sternberg, Wolfgang. The general limit theorem in the theory of probability. Read Oct. 28, 1939. This Bulletin, vol. 46, no. 4 (April, 1940), pp. 292-298.

Stoker, J. J. Unbounded convex point sets. Read Feb. 26, 1938. American Journal of Mathematics, vol. 62, no. 1 (Jan., 1940), pp. 165-179. See Friedrichs, K. O.

Swingle, P. M. A finitely-containing connected set. Read April 15, 1939. This Bulletin, vol. 46, no. 2 (Feb., 1940), pp. 178-181.

Szász, Otto. On the order of the partial sums of Fourier power series. Read April 15, 1939. This Bulletin, vol. 46, no. 2 (Feb., 1940), pp. 108-112.

- On strong summability of Fourier series. Read Dec. 26, 1939. Transactions of this Society, vol. 48, no. 1 (July, 1940), pp. 117-125. See Barnett, I. A.

Szegö, Gabor. On the gradient of solid harmonic polynomials. Read Sept. 8, 1939. Transactions of this Society, vol. 47, no. 1 (Jan., 1940), pp. 51-65.

- Remarks on a note of Mr. R. Wilson and on related subjects. Read Feb. 24, 1940. This Bulletin, vol. 46, no. 10 (Oct., 1940), pp. 852-858. See Schaeffer, A. C.

Taylor, A. E. The weak topologies of Banach spaces. Read Nov. 26, 1938. Revista de Ciencias, vol. 42, no. 432 (June, 1940), pp. 355-366.

Thurman, G. R. See Blumenthal, L. M.

Tornheim, Leonard. Integral sets of quaternion algebras over a function field. Read April 8, 1938. Transactions of this Society, vol. 48, no. 3 (Nov., 1940), pp. $436-450$.

Torrance, E. M. Superposition on monotonic functions. Read Sept. 6, 1938. Duke Mathematical Journal, vol. 6, no. 2 (June, 1940), pp. 307-317.

Trjitzinsky, W. J. Some problems in the theory of singular integral equations. Read Dec. 27, 1939. Annals of Mathematics, (2), vol. 41, no. 3 (July, 1940), pp. 584-619.

Tucker, A. W. The algebraic structure of complexes. Read Oct. 28, 1939. Proceedings of the National Academy of Sciences, vol. 25, no. 12 (Dec., 1939), pp. 643-647.

Vance, E. P. Generalizations of non-alternating and non-separating transformations. Read April 15, 1939. Duke Mathematical Journal, vol. 6, no. 1 (March, 1940), pp. 66-79.

Vassell, Annette. A complete characterization of sectional families of curves. Read Feb. 25, 1939. American Journal of Mathematics, vol. 62, no. 4 (Oct., 1940), pp. 813-822.

Vickery, C. W. Axioms for Moore spaces and metric spaces. Read April 20, 1935. This Bulletin, vol. 46, no. 6 (June, 1940), pp. 560-564.

Wagner, R. W. An extension of analytic functions to matrices. Read April 9, 1937 and April 8, 1938. American Journal of Mathematics, vol. 62, no. 2 (April, 1940), pp. 380-390.

Walker, R. J. See Rosser, Barkley.

Wall, H. S. Continued fractions and totally monotone sequences. Read Feb. 24, 1940. Transactions of this Society, vol. 48, no. 2 (Sept., 1940), pp. 165-184.

- See Garabedian, H. L.; Scott, W. T.

Wallace, A. D. Monotone coverings and monotone transformations. Read Dec. 30, 1938. Duke Mathematical Journal, vol. 6, no. 1 (March, 1940), pp. 31-37. 
- On 0-regular transformations. Read April 15 and 16, 1938. American Journal of Mathematics, vol. 62, no. 2 (April, 1940), pp. 277-284.

Walsh, J. L. On the degree of convergence of sequences of rational functions. Read Dec. 30, 1938. Transactions of this Society, vol. 47, no. 2 (March, 1940), pp. 254-292.

- Note on the degree of convergence of sequences of analytic functions. Read Dec. 30, 1938. Transactions of this Society, vol. 47, no. 2 (March, 1940), pp. 293-304.

Walsh, J. L., and Sewell, W. E. Sufficient conditions for various degrees of approximation by polynomials. Read Sept. 5, 1936. Duke Mathematical Journal, vol. 6, no. 3 (Sept., 1940), pp. 658-705.

Ward, Morgan. The arithmetical properties of modular lattices. Read Sept. 8, 1939. Revista de Ciencias, vol. 41, no. 430 (Dec., 1939), pp. 593-603.

— Residuated distributive lattices. Read Dec. 2, 1939. Duke Mathematical Journal, vol. 6, no. 3 (Sept., 1940), pp. 641-651.

Warschawski, S. E. See Galbraith, A. S.

Weyl, Hermann. Theory of reduction for arithmetical equivalence. Read Feb. 24, 1940. Transactions of this Society, vol. 48, no. 1 (July, 1940), pp. 126-164.

Whitmore, W. F. Convergence theorems for functions of two complex variables. Read Dec. 2, 1939. American Journal of Mathematics, vol. 62, no. 3 (July, 1940), pp. 687-696.

Whitney, Hassler. Some combinatorial properties of complexes. Read Feb. 25, 1939. Proceedings of the National Academy of Sciences, vol. 26, no. 2 (Feb., 1940), pp. 143-148.

Whyburn, G. T. A relation between non-alternating and interior transformations. Read Sept. 8, 1939. This Bulletin, vol. 46, no. 4 (April, 1940), pp. 320-321. See Hall, D. W.

Williamson, John. An algebraic problem involving the involutory integrals of linear dynamical systems. Read Feb. 24, 1940. American Journal of Mathematics, vol. 62, no. 4 (Oct., 1940), pp. 881-911.

Winston, Clement. On mechanical quadratures formulae involving the classical orthogonal polynomials. Read Oct. 31, 1931. Annals of Mathematics, (2), vol. 35, no. 3 (July, 1934), pp. 658-677.

Wyman, Max. The simultaneous theory of two linear connections in a generalized geometry with Banach coordinates. Read Nov. 26, 1938. Compositio Mathematica, vol. 7, no. 3 (Feb., 1940), pp. 436-446.

See Michal, A. D.

Youngs, J. W. T. K-cyclic elements. Read Sept. 8, 1939. American Journal of Mathematics, vol. 62, no. 2 (April, 1940), pp. 449-456.

- See Radó, Tibor.

Zippin, Leo. See Montgomery, Deane.

Zuckerman, H. S. See Birnbaum, Z. W. 